servants sought to dissociate themselves from Sir Keith Joseph's disastrous green paper on higher education). The manipulation of information in this way is bound in the long run to undermine public understanding of what the government is doing even if, in the short run, it renders ministers more powerful and relatively immune from criticism.

Britain's complacent tolerance of these ways of doing government business probably implies that there is little hope of change. Yet, the Westland affair is merely the most spectacular of the ways in which even governments are caught out by their own malpractices. Why should not Mr Brittan have denied receiving a letter from British Aerospace (it had been sent to the Prime Minister) when he had no reason to fear that it would be made public? And why should he not have leaked another knowing that such things go on all the time?

The less spectacular damage done to British public life by this seamy side of the British constitution is even more serious. The violent swings of policy on important issues such as education and the management of the economy have done great damage, wasting time and resources and creating a general sense of uncertainty within Britain and outside. The convention that only ministers matter is not only bad for their opinions of themselves (and their manners) but means that government policy is often no more convincing than the person who happens for the time being to be its personal embodiment. Legalized secrecy modified by vicarious and selective leaking, which may be as damaging to governments (as the past few weeks have shown) as to their electors, saps people's confidence in the process of government. And the personality traits which this poisonous combination of malpractices engenders are infectious. All the way down the hierarchy of government, there are civil servants and the chairmen of public corporations who enjoy the power of keeping secrets - and of letting some of them slip. The folly of the second part of the Official Secrets Act was acknowledged almost a decade ago (and Mrs Thatcher's predecessor promised at one stage to get rid of it). Might not she start where he gave up, and offer some such reform as expiation in the trouble she has stumbled into?

\section{Max-Planck survives}

The 75th anniversary of the Max-Planck-Gesellschaft is a time for celebration.

THE Max-Planck-Gesellschaft is celebrating its seventy-fifth anniversary this year with a greater sense of security than would have been possible at any previous time since its formation, as the Kaiser-Wilhelm Gesellschaft, in the deceptively secure days just before the First World War. Originally the vision of the theologian Adolf Harnack (who was the society's president until 1930), the first two institutes had hardly been founded on the plot of ground donated by the Kaiser at Berlin-Dahlem before the Great War began. In what must have seemed bewilderingly quick succession, there followed the financial storm of the 1920 s, the Nazi government and the Second World War. Only since the society was allowed to begin again, temporarily at Gottingen, in 1946, can it have seemed as if the stability promised by the founding fathers might yet materialize. In the event, the society was formally reconstituted, with its present name (wished on it by the British army then in occupation of Lower Saxony), only in February 1948.

Among publicly supported research organizations, the MaxPlanck or MPG is distinctive and may even be unique. The original conception, that of a network of free-standing research institutes devoted largely to basic research, was not merely in 1911 quite different from anything elsewhere, but was a break with the traditions of German scholarship which, throughout the nineteenth century, had turned around the doctrine of Wilhelm ron Humbolt that teaching and research are inseparable. Part of vrnack's ambition was that German science (which, in the old tradition, covers the humanities as well) should secure a measure of independence that the German universities could not then aspire to. This was to be secured by setting up the society with a generous endowment, and 10 million marks of the day were indeed collected in the three months before the KaiserWilhelm Gesellschaft came into being at $11.00 \mathrm{a} . \mathrm{m}$. on $11 \mathrm{Janu}-$ ary 1911. At the outset, the society was responsible for its own running costs and capital works, although the government paid the salaries of institute directors, but the inflation of the $1920 \mathrm{~s}$ quickly put paid to that, even though the society was still clever enough to recruit Einstein from Switzerland. Mercifully, the doctrine of independence survived, at least until the National Socialists took office in 1933

There followed the society's most difficult period. The edict that Jews were unwelcome became the law. Fritz Haber resigned because two of his division heads had to be expelled for being Jewish. Carl Neuberg, director of the institute for biochemistry, was forced into early retirement and eventually, in 1939, forced to leave Germany altogether. Between 1933 and 1938, nearly a third of all the scientific members of the society were forced out, mostly on racial grounds. Max Planck himself, who had succeeded Harnack as president and who believed that the Nazis would disappear as quickly as they had arrived, resigned once the twenty-fifth anniversary had passed.

It says much for the strength of the network of the 1930s that it was somehow able to survive the Second World War. The British insistence that the name should be changed was natural in the circumstances. The remarkable feature of the post-war reconstitution is that nobody thought it feasible to change the constitution that, among other things, gives the members of the society the right to elect their president. The result, in the circumstances of post-war West Germany, is that the government of the Federal German Republic naturally regarded MPG as a means by which West German science could be rapidly strengthened. Especially during the 1960 s and 1970 s, the network of research institutes grew quickly. Now there are sixty of them, with a total strength of 10,000 people of whom 4,000 are scientists. They range in size and scope from huge research establishments such as that for plasma physics at Garching near Munich to small informal places, hardly distinguishable from university departments, such as that for mathematics at Bonn. MPG has an annual budget of DM 1,000 million, which is a mere 2.2 per cent of what West Germany spends on research each year. Its influence inside and outside West Germany is disproportionately great.

Why has the organization succeeded so well? Part of the explanation is that the institutes have indeed allowed people to get on with research, free from teaching and administrative duties. But the network has cleverly done its best to avoid the obvious danger that it will become ingrown by insisting on its right to hire people from outside West Germany, both as investigators and as advisers. MPG has also been able to insulate its people from the social upheaval in the universities that has occupied much of the past twenty years. In many ways, it has had an easier task than its publicly supported partner in research support, the Deutscheforschungsgemeinschaft (DFG), with a budget of roughly the same size and a remit to support basic research in the universities.

Not everything is cheerful, however. Self-consciously though it has tried, MPG has not preserved all its institutes from inwardness. Now, with a static budget, the going may be harder; starting a new institute seems to require that one already in being should be closed. Moreover, the days when MPG seemed the best way to strengthen West German science have gone. The universities are stronger now, as is West German science as a whole. The obvious need is to forge better links between the universities and the sometimes still too-independent research institutes. It is good news that MPG appears to recognize the need; something like ten per cent of its scientific staff now double as university teachers. But there is still some way to go. $\square$ 